\title{
School Committee Support for Improving the Quality of Education Services
}

\author{
Endang Sri Budi Herawati ${ }^{1, \text { a), }}$ Naufalia Nuraya ${ }^{1)}$, Adiman ${ }^{1)}$, and Rusi Rusmiati \\ Aliyyah $^{2)}$ \\ ${ }^{1)}$ Faculty of Teaching and Education, Universitas Nahdlatul Ulama Cirebon, Cirebon, 45122, Indonesia \\ ${ }^{2)}$ Faculty of Teaching and Education, Universitas Djuanda, Bogor, 5720, Indonesia \\ a)Corresponding author: endangsribudiherawati@gmail.com
}

\begin{abstract}
Education should not just be the responsibility of the government. The community should play an active role in supporting the implementation of education, especially in the region. Community participation in the education unit level is in a container called the School Committee. The optimization of school committee support will help improve education services in schools. This research aims to find out the school committee's support for implementing education in schools by implementing its roles and functions. The research approach used is to study Pustaka studies. The review was conducted on the government's rules on school committees and the results of previous studies that have been published. This research shows that the School Committee has four roles: advisory agency role, supporting agency role, controlling agency, and mediator. If the School Committee is empowered optimally, it will provide positive support in improving schools' quality of education services.
\end{abstract}

Keywords: School Committee, Quality of Education Services, Community Participation.

\section{INTRODUCTION}

Efforts to improve education quality are not simple but require multidimensional handling involving various parties involved [1]. This is a logical consequence of the education sector's autonomy and the rolling concept of decentralization. The community becomes the most decisive party to the implementation and implementation of the education system in the region because the city becomes a source of funding for the performance of education in the area [2]. The concrete impartiality of the community at the level of the education unit is in the School Committee. The School Committee is an independent body that accommodates community participation to improve the quality, equalization, and efficiency of education management in the education unit, both on preschool education pathways, school education pathways, and out-of-school education pathways [3]. School Committee consists of parents/guardians of students, school communities, and community leaders who care about education [4]. Community contributions in education can be built through school committees, where student parents' awareness can continue to be made at least in their respective schools to support school programs' implementation [5].

The establishment of the School/Madrasah Committee became more potent than the legal aspects because it has been accommodated in Article 56 of Law No. 20 of 2003 on the National Education System as follows: (1) The community plays a role in improving the quality of education services which include planning, supervision, and evaluation of education programs through the board of education and school 
committees/madrassas; (2) The school/madrassa committee, as an independent institution, is formed and plays a role in improving the quality of education by providing consideration, direction, and support of personnel, facilities, and homework, as well as educational supervision at the level of the education unit [6].

School committees were formed to contribute to improving the quality of education services actively. Kepmendiknas No. 044/U/2002 explains the objectives of the establishment of the school committee are: (1) to accommodate and channel the aspirations and initiatives of the community in the delivery of operational policies and educational programs in the education unit; (2) Increase the responsibility and participation of the city in the maintenance of education in the education unit; (3) Creating an atmosphere and conditions of transparency, accountability, and democracy in the implementation and service of quality education in the education unit [3]. The duties carried out by the school committee in supporting the improvement of the quality of education services are:
(1) consider the determination and implementation of education policy; (2) raise funds and other educational resources from the community either individual/organization/business/industrial world or other stakeholders through creative and innovative efforts; (3) supervise education services in schools by the provisions of the laws and regulations; and (4) follow up on complaints, suggestions, criticisms, and aspirations from students, parents/guardians, and the community as well as the results of the School Committee's observations on school performance [4].

School committees have a strategic role in realizing "School Communities" loyal to improving schools' quality of education services. The parts are: (1) as advisory agencies in various education policies made by schools; (2) supporting agency roles both financially, thought donation, and the energy required by the school; (3) the part of controlling agency to promote transparency and accountability of education; and (4) as a mediator between parents of students with schools and governments (education agencies).

Table 1. Description of School Committee Roles and Functions Into Operational Activities School Committee

\begin{tabular}{|c|c|}
\hline \multicolumn{2}{|l|}{ Advisory agency } \\
\hline Function & Operational forms of activities \\
\hline $\begin{array}{l}\text { Provide input, consideration, and } \\
\text { recommendations to the education } \\
\text { unit on (1) education policies and } \\
\text { programs, (2) RAPBS, (3) the } \\
\text { performance criteria of the } \\
\text { education unit, (4) the criteria of } \\
\text { the education workforce, (5) the } \\
\text { criteria of educational facilities, } \\
\text { and (6) other things related to } \\
\text { education. }\end{array}$ & $\begin{array}{l}\text { 1. To record the socioeconomic condition of students' families and } \\
\text { educational resources in the community. } \\
\text { 2. Analyze the results of logging as material for input, consideration, and } \\
\text { or recommendation to the school } \\
\text { 3. Submit feedback, considerations, and or recommendations in writing to } \\
\text { the school, with a copy to the Education Officer and the Board of } \\
\text { Education. } \\
\text { 4. Consider the school to develop a local content curriculum. } \\
\text { 5. Consider schools to improve the fun learning and teaching process } \\
\text { (PAKEM) } \\
\text { 6. Provide input and consideration to the school in the preparation of } \\
\text { school vision, mission, objectives, policies, and activities }\end{array}$ \\
\hline \multicolumn{2}{|l|}{ Supporting Agency } \\
\hline Function & Operational forms of activities \\
\hline $\begin{array}{l}\text { Encourage parents and } \\
\text { communities to participate in } \\
\text { education. }\end{array}$ & $\begin{array}{l}\text { 1. Hold regular and incidental meetings or meetings with parents and } \\
\text { members of the public. } \\
\text { 2. Seeking funding from businesses and industries for tuition waiver fees } \\
\text { for students from families unable to afford } \\
\text { 3. Encourage and approach parents and communities that are seen as } \\
\text { speakers in extracurricular activities for students. } \\
\text { 4. Provide support for children's health screening } \\
\text { 5. Provide support to schools to preventatively and curatively eradicate the } \\
\text { dissemination of drugs in schools } \\
\text { 6. Provide support to the school in the implementation of extracurricular } \\
\text { activities in the school. }\end{array}$ \\
\hline $\begin{array}{l}\text { We are raising public funds to } \\
\text { finance the implementation of } \\
\text { education. }\end{array}$ & $\begin{array}{l}\text { 1. Verify the bill submitted by the principal } \\
\text { 2. Ratify the Budget after the verification process in the plenary meeting } \\
\text { of the School Committee } \\
\text { 3. Motivate the upper middle class to increase its commitment to efforts to } \\
\text { improve the quality of education in schools }\end{array}$ \\
\hline
\end{tabular}




\begin{tabular}{|c|c|}
\hline & $\begin{array}{l}\text { 4. Assist the school in the framework of community fundraising for lasting } \\
\text { fundraising. }\end{array}$ \\
\hline $\begin{array}{l}\text { Encouraging the growth of public } \\
\text { attention and commitment to the } \\
\text { implementation of quality } \\
\text { education }\end{array}$ & $\begin{array}{l}\text { 1. Implement the concept of cross-subsidy in withdrawing dues from } \\
\text { parents of students. } \\
\text { 2. Hold innovative activities to increase community awareness and } \\
\text { commitment, such as an entertainment stage for schools and } \\
\text { communities. } \\
\text { 3. Assist the school in creating relationships and Cooperation between the } \\
\text { school and parents and the community. }\end{array}$ \\
\hline \multicolumn{2}{|l|}{ Controlling Agency } \\
\hline Function & Operational forms of activities \\
\hline $\begin{array}{l}\text { To evaluate and supervise } \\
\text { education policies, programs, } \\
\text { implementation, and output. }\end{array}$ & $\begin{array}{l}\text { 1. Hold regular or incidental meetings or meetings with principals and } \\
\text { teacher councils. } \\
\text { 2. Frequent visits or visits to schools, or with teacher councils in schools } \\
\text { 3. Ask the school for an explanation of the student's learning outcomes. } \\
\text { 4. Cooperate with the school in alumni search activities }\end{array}$ \\
\hline \multicolumn{2}{|r|}{ 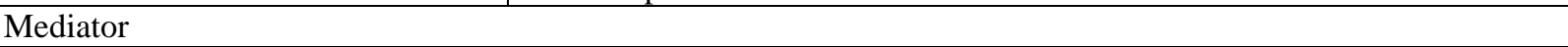 } \\
\hline Function & Operational forms of activities \\
\hline Cooperate with the community & $\begin{array}{l}\text { 1. Foster harmonious relationships and Cooperation with all educational } \\
\text { stakeholders, especially with DUDI } \\
\text { 2. Conduct rationing about the possibility to be able to conduct } \\
\text { Cooperation or MoU with other institutions to advance the school }\end{array}$ \\
\hline $\begin{array}{l}\text { Accommodate and analyze } \\
\text { aspirations, ideas, demands, and } \\
\text { various educational needs } \\
\text { submitted by the community }\end{array}$ & $\begin{array}{l}\text { 1. Distribute questionnaires to get feedback, suggestions, and creative } \\
\text { ideas from the community. } \\
\text { 2. Submit a report to the school in writing about the results of its } \\
\text { observations at the school. }\end{array}$ \\
\hline
\end{tabular}

Source: Operational Reference and Performance Indicators of the School Committee [7].

Some research has concluded that school committees are needed to provide support to improve the quality of education services through the implementation of their roles and functions [8] [9] [10]. However, there is still a perception that the School Committee's existence has not contributed significantly. It indicated that the school committee is only a symbol to sign the proposal in asking certain parties for assistance, both government and private parties [11]. The School Committee is considered a tool to launch school programs and incriminate parents to collect donations [12]. Some research also mentioned that the role of school committees in improving the quality of education services is not optimal [13] [14] [15]. This research is intended to discuss more in support of school committees for implementing education in schools by implementing their roles and functions, based on literature studies of the results of previous research studies.

\section{METHOD}

This research is a qualitative descriptive study, which is a study that produces descriptive data in the form of written words based on behavioral observations or explanations of people. In this study, the information was collected based on information obtained from library searches. Literature studies are conducted by collecting several previous research results relevant to the topic of research. The research results are considered a source of data obtained and analyzed to get the complete information as a conclusion.

\section{RESULTS AND DISCUSSION}

The school committee's existence in the education unit is an institution that coordinates parents of students' participation in the service of education in the school. This strategic role makes school committees should be optimized for their roles and functions. Therefore, the principal needs to establish unified communication with the school committee so that the school program to improve the quality of education is carried out correctly. Among the efforts that the principal can make is to involve the school committee in the preparation of the school program, including in the implementation, and request an evaluation at the end of the program implementation. The school committee's role needs to continue to be encouraged and optimized to improve the quality of education run as expected. The School Committee is expected to carry out its roles and functions as support in implementing the learning process in line with each school's environmental conditions and 
problems [16]. Consent to the school was realized in implementing the school committee's four roles stipulated in The Ministry of Education No.044/U/2002.

\subsection{Advisory Agency}

The advisory agency's role by the school committee is to provide input, consideration, and recommendations to the education unit on (1) education policies and programs, (2) the Budget, (3) the performance criteria of the education unit, (4) the criteria of the education workforce, (5) the criteria of educational facilities, and (6) other things related to education [7]. The results of the research conducted by Hasna Rita concluded that the school committee embodies the role of the consideration in the form of providing input of the learning process to teachers, review of the provision and use of facilities and infrastructure, care of the service and utilization of the Budget, information on the draft budget of the revenue and expenditure of the school/madrasah $(R A P B S / M)$, the consideration of changes and co-authorizing the Budget with the principal [17]. The school engages the school committee in the learning program and provides learning support facilities in the school.

This is in line with research conducted by Sri Wardiah, Murniati and Djailani concluded that the school committee's strategy in improving the quality of education is carried out through activities: (1) Regular meetings with school residents at the end of each semester; (2) Together the school formulates the vision and mission of the school, compiling RKAS and RAPBS; and (3) develop the potential for better direction [18]. Thus, the school should ask the school committee to formulate its policies, programs, and activities, including developing its vision, mission, and objectives. The consideration stipulated by the School Committee is based on trust, respect, and commitment to realize a shared vision so that the School Committee must participate in developing a shared vision and school progress plans and implementing continuous improvements in school programs or services for students and parents [19].

The school committee has done some important things to improve the quality of education, including working with various communities around the school in expanding the network of Cooperation between the school and the district in the form of community involvement in the making of multiple policies for school development [18]. According to Raynolds, the School Committee's attitude and responsibility in considering the early stages of joint activities with the school community, namely building a vision of a shared future, because a shared vision is a key to implementing the role of the School Committee. The purpose of the joint invention is to determine the overall direction of the school committee's activities and decisions, provide one common language to use in discussions about education programs and school services as a perfect picture for the future, and become a working document for now [20]. In a nutshell, Indra Jati Sidi expressed his opinion that the School Committee can consider the form of assessment input for the development of educational implementation, both extracurricular and extracurricular, and the implementation of school management which includes principals, teachers, students, and employees, as well as considering the discussion of the proposed Budget [21].

\subsection{Supporting Agency}

School committees as supporting bodies play a role in creating Cooperation between schools, parents, and communities and providing facilities and infrastructure [22]. The supporting agency played by the school committee can be financial support, thought, and energy in the implementation of education in schools. Quoted from the Operational Reference and Performance Indicators of the School Committee, this supporting role is aimed at: (1) Encouraging parents and communities to participate in education; (2) Raise public funds to finance the implementation of knowledge; (3) Encouraging the growth of public attention and commitment to the implementation of quality education [7]. Ivan Hanafi and Mufti Ma'sum's research made clear that the School Committee's support for improving the quality of education includes: (1) input components: curriculum, human resources (HR), student programs, infrastructure facilities, and school finances; (2) process components: learning activities, intra, and extracurricular activities, and spiritual guidance; (3) output components: academic and non-academic achievement [23].

It is understood that supporting roles are essential for the implementation of quality education. School committee support in both material and thoughtprovoking advice/donations can improve schools' quality of education. The problem with school committees in improving the quality of education is the lack of communication between schools and school committees due to the lack of time that school committees have, making school committee programs less effective [18]. Therefore, it is necessary to establish good communication between the school and the school committee. Also, there needs to be a clear commitment from the committee board to play an active role in implementing its parts and functions. The committee's strength stems from activeness, follow-up work, clear division of labor, and good coordination [24]. Supporting factors in the role of the school committee are (a) the high commitment of the school committee to assist the school; (b) support for ideas, energy, and adequate facilities; (c) establish good communication and coordination; (d) education background of school committee members [13]. 


\subsection{Controlling Agency}

Controlling school maintenance is a fundamental task and role for school partner institutions such as school committees. The School Committee needs to supervise learning activities in schools to improve students' quality and learning outcomes. This is in line with the research of Tiara Erwinda, Rwanda, and Herpratiwi, which explained that school committees as a control body play a role in controlling teacher performance, monitoring organizations in schools, and monitoring output in schools [22]. This role is intended to encourage accountability and transparency of schools in the implementation of education. Responsibility includes (1) school performance; (2) school quality; (3) school resources; (4) outcome education. At the same time, transparency includes: (1) the implementation of educational programs and activities; (2) preparation of school development plan (RPS); (3) school revenue and expenditure budget plan (RAPBS) [15]. Supervision conducted by school committees is not institutional oversight as carried out by institutions or supervisory bodies such as inspectorates, Financial Examiner Bodies, or other functional oversight bodies. Social supervision has more social implications and is more preventively implemented, such as when schools draft budgets or compile accountability reports to the community [25].

Supervision in the implementation of education will give rise to public trust in the school. This role must be exercised by the School Committee on education policy, programs, performance, and output. The forms of activities that can be carried out by the school committee to carry out this role are: (1) Hold regular or incidental meetings or meetings with the principal and teacher council; (2) Frequent visits or visits to schools or with teacher councils in schools; (4) Ask the school for an explanation of the student's learning outcomes; (4) Cooperate with the school in alumni search activities [7].

\subsection{Mediator}

Hasnarita's research explains that the school committee's role as a mediator is in the form of a liaison between the principal and the community, the principal with the board of education, and the principal with the school itself [17]. Furthermore, Tiara Erwinda's research, et al., provides information that the performance of the school committee in carrying out its mediator role is carried out in a way: (1) socializing school programs and policies to the community; (2) facilitate input from the community on school policies/programs; (3) accommodate complaints and complaints related to school policy [22]. This is in line with the School Committee's duty to follow up on complaints, suggestions, criticisms, and aspirations from students, parents/guardians, and the community as well as the results of the School Committee's observations on school performance [26].

It is understood that the school must establish a good relationship with the surrounding environment/community. This is done so that the school program gets support from the city. Also, schools can benefit the communities around the school. This is in line with Ngalim Purwanto's opinion that the development of the school and community relations aims to: (1) Maintain the survival of the school; (2) Improve the quality of education in the school concerned; (3) Facilitate the learning process; (4) Obtain support and assistance from the community necessary in the development and implementation of school programs [27]. The role of mediators carried out by the school committee includes two groups, namely: (1) cooperating with the community, in the form of (a) fostering harmonious relationships and Cooperation with all educational stakeholders, especially with DUDI; (b) conduct rationing about the possibility of being able to conduct Cooperation or MoU with other institutions to advance the school. (2) accommodate and analyze the aspirations, ideas, demands, and various educational needs put forward by the academic community by (a) disseminating questionnaires to obtain feedback, suggestions, and creative ideas from the city; (b) submit a report to the school in writing about the results of its observations to the school [7]. Establishing Cooperation with the community should be based on the similarity of responsibilities and objectives between educational institutions and the organization concerned. Because somehow, the school belongs to the city because the raw input of the school itself comes from the city, and the output of the school will later be returned to the community [16].

\section{CONCLUSIONS}

Based on the literature study, this study explains that the role of school committees as advisory agencies, supporting agencies, controlling agencies, and mediators will provide support for the improvement of the quality of education services in schools. The existence of the school committee is a great hope in the development of the school. If these roles are optimized, the school program will be implemented properly. So that the quality of education services will develop in a good direction as well. The operational forms of implementing the role of the school committee are: (1) providing input, consideration, and recommendation to the education unit concerning (a) education policies and programs, (b) the rapbs, (c) the performance criteria of the education unit, (d) the criteria of the education workforce, (e) the criteria of educational facilities, and (f) other matters related to education; (2) encourage parents and communities to participate in education; (3) raise public funds to finance 
the implementation of education; (4) encourage the growth of public attention and commitment to the implementation of quality education; (5) evaluate and supervise education policies, programs, implementation, and outputs; (6) cooperate with the community; (7) accommodate and analyze the aspirations, ideas, demands, and various educational needs put forward by the community.

\section{REFERENCES}

[1] A. Khaliq, "Manajemen Partisipasi Masyarakat dalam Pendidikan pada Mts Muhammadiyah 3 Al-Furqon Banjarmasin," TRANSFORMATIF, vol. 1, no. 1, p. 16, Dec. 2017, doi: 10.23971/tf.v1i1.666.

[2] E. Herawati, S. Suryadi, and B. Sujanto, "The Role and Function of Board Education To Improving Education Services Quality," in International Conference on Environmental Awareness for Sustainable Development in conjunction with International Conference on Challenge and Opportunities Sustainable Environmental Development, ICEASD \& ICCOSED, 2019, DOI: 10.4108/eai.1-42019.2287253.

[3] Depdiknas, Kepmendiknas No 044/U/2002 Tentang Dewan Pendidikan dan Komite Sekolah. 2002.

[4] Kepmendikbud, Peraturan Menteri Pendidikan Dan Kebudayaan Republik Indonesia Nomor 75 Tahun 2016 tentang Komite Sekolah. Departemen Pendidikan dan Kebudayaan Republik Indonesia, 2016.

[5] E. S. B. Herawati, S. Suryadi, and B. Sujanto, "Evaluating the Implementation of Policy on Education Board," Int. J. Educ. Vocat. Stud., vol. 1, no. 3, pp. 236-243, Jul. 2019, DOI: 10.29103/ijevs.v1i3.1584.

[6] UU SISDIKNAS NO 20 TAHUN 2003. .

[7] Tim Pengembangan Dewan Pendidikan dan Komite Sekolah Dirjen Dikdasmen Departemen Pendidikan Nasional, Acuan operasional dan indikator kinerja Komite Sekolah. 2003.

[8] S. Pamungkas, A. Eddison, and Haryono, "A Study Community Perceptions of The Role of School Committes in SMPN 1 Tandun Rokan Hulu District," J. Online Mhs. Bid. Kegur. dan Ilmu Pendidik., vol. 7, no. 1, pp. 1-10, 2020.

[9] L. Yuliana, "Peran Komite Sekolah dalam Mewujudkan Sekolah Efektif," J. Ilm. WUNY, vol. 18, no. 2, pp. 28-38, Jul. 2016, doi: 10.21831/jwuny.v18i2.10003.

[10] F. Fikriadi, R. Rusdiawan, and S. Wilian, "Kontribusi Kinerja Komite Sekolah dan Kepemimpinan Kepala Sekolah Terhadap Mutu
Pembelajaran di SMAN 1 Tanjung Kabupaten Lombok Utara," J. Ilm. Profesi Pendidik., vol. 2, no. 1, pp. 45-54, Feb. 2017, doi: 10.29303/jipp.v2i1.38.

[11] ZULKIFLI, "Komite Sekolah Di Antara Cita Dan Realita," POTENSIA J. Kependidikan Islam, vol. 14, no. 1, pp. 99-127, 2015.

[12] E. S. B. Herawati, J. Warlizasusi, and R. R. Aliyyah, "Kinerja Dewan Pendidikan Dalam Meningkatkan Mutu Pendidikan," Tadbir J. Stud. Manaj. Pendidik., vol. 4, no. 1, p. 87, May 2020, doi: 10.29240/jsmp.v4i1.1435.

[13] Z. Hamdi and S. B. Wahyono, "Pemberdayaan Komite Sekolah Untuk Peningkatan Mutu Pendidikan Dalam Implementasi Kurikulum 2013 Di SD Negeri," J. DIDIKA Wahana Ilm. Pendidik. Dasar, vol. 3, no. 2, pp. 35-55, 2018, doi: 10.29408/didika.v3i2.680.

[14] Satria, H. F. AR, and Zulkarnain, "Evaluasi Peran Komite Sekolah (Studi Kasus di SMAN 1 Bangko Pusako)," J. Manaj. Pendidikan, Penelit. Kualitatif, vol. 2, no. 3, pp. 264-272, 2017.

[15] W. Emelda, Sulaiman, and R. Elly, "Peran Komite Sekolah sebagai Pengontrol dalam Penyelenggaraan Pendidikan di Gugus SD Negeri Lambada Klieng Aceh Besar," J. Ilm. Pendidik. Guru Sekol. Dasar, FKIP Unsyiah, vol. 3, no. 4, pp. 202-209, 2018.

[16] Y. Endra Megiati, "Pemberdayaan Komite Sekolah: Kajian Konsep dan Implementasinya," SAP (Susunan Artik. Pendidikan), vol. 1, no. 2, pp. 125-134, 2016, doi: 10.30998/sap.v1i2.1019.

[17] Hasnarita, "Peran Komite dalam Penyelenggaraan Pendidikan di Madrasah Tsanawiyah Negeri 1 Palembang (Studi Manajemen Peningkatan Mutu Berbasis Sekolah)," Conciencia, vol. 17, no. 1, pp. 70-80, Jan. 2018, doi: 10.19109/conciencia.v17i1.1583.

[18] S. Wardiah, Murniati, and Djailani, "Strategi Komite Sekolah Dalam Peningkatan Mutu Pendidikan Di Sd Negeri 1 Lhoknga," J. Adm. Pendidik. Progr. Pascasarj. Unsyiah, vol. 3, no. 2, pp. 12-21, 2015.

[19] A. Asasi Syam, S. Syamsudduha, and M. Khalifah Mustamin, "Peran Komite Sekolah Sebagai Advisory Agency dalam Implementasi Manajemen Berbasis Sekolah di SMA Negeri 19 Bone," J. Diskurs. Islam, vol. 5, no. 3, pp. 548569, Dec. 2017, doi: 10.24252/jdi.v5i3.7087.

[20] Larry J Raynolds (terjemahan Teguh Budiharsono), Kiat Sukses Manajemen Berbasis Sekolah; Pedoman bagi Praktisi Pendidikan., Edisi terj. Jakarta: Diva Pustaka, 2005. P: 166

[21] I. J. Sidi, Menuju Masyarakat Belajar: Menggagas Paradigma Baru Pendidikan, Cetakan I. Jakarta: Logos Wacana Ilmu, 2001. P: 
135

[22] T. Erwinda, Riswandi, and Herpratiwi, "Studi Analisis Peranan Komite Sekolah di SD AlAzhar Bandar Lampung," J. Pedagog. FKIP Unila, vol. 8, no. 3, pp. 1-14, 2018.

[23] I. Hanafi and M. Ma'sum, “Analisis Implementasi Kebijakan Pendidikan: Peran Komite Sekolah Pada Sekolah Menengah Kejuruan," Cakrawala Pendidik., vol. 2, no. 1, pp. 58-66, 2015, doi: 10.21831/cp.v1i1.4176.

[24] D. N. Septiana, I. Bafadal, and D. E. Kusumaningrum, "Pelibatan Komite Sekolah Dalam Peningkatan Mutu Pendidikan," J. Adm. dan Manaj. Pendidik., vol. 1, no. 3, pp. 293-301, 2018, doi: 10.17977/um027v1i32018p293.

[25] E. E. P. Sari, "Peran Komite Sekolah dalam Mendukung Peningkatan Mutu SD Muhammadiyah Wirobrajan 3 Yogyakarta Tahun Ajaran 2014 / 2015 (Skripsi)," Universitas PGRI Yogyakarta, 2015.

[26] Permendikbud No 75 tahun 2016 tentang Komite Sekolah. 2016.

[27] M. N. Purwanto, Administrasi dan Supervisi Pendidikan. Bandung: Remaja Rosdakarya, 2010. P. 189 